\title{
Чикаго стил библиографског цитирања
}

\author{
Драгана Сабовљев \\ Градска народна библиотека „Жарко Зрењанин“, Зрењанин \\ dragana.sabovljev@gmail.com
}

\section{Сажетак}

Цитирање као дословно навођење туђих речи, парафраза или резиме нечијих идеја или ставова у циљу потврђивања сопствених сазнања, полемике са супротним мишљењима, или као упућивање читаоца на сродне радове, захтева јасан и исцрпан библиографски опис извора. То подразумева правила по којима се наводе подаци о библиографској јединици која варирају од једног до другог стила цитирања. Избор зависи од научне дисциплине, правила која прописују часописи или зборници у којима се објављују радови, или од афинитета самих аутора. У овом тексту, на практичним примерима, представљене су измене у начину цитирања појединих врста грађе и извора објављене у 17. издању Чикаго стила библиографског цитирања (Chicago Style) из 2017. године. Редакција Читалишта: научног часописа за теорију и праксу библиотекарства, у складу са традицијом заступљеном у часописима са тематиком из библиотечко-информационе делатности у свету, определила се за Notes and Bibliography style (односно Humanities Style). У овом тексту су приказани начини навођења различите библиотечко-информационе грађе и извора који се најчешће користе као референсна литература у научном или стручном раду.

Кључне речи: цитирање, Чикаго стил библиографског цитирања, Приручник Чикаго стила (The Chicago Manual of Style CMOS) (2017), библиографска јединица, фуснота, литература, библиотечко-информациона грађа, извори

\section{Уводне напомене}

Чикаго стил (Chicago Style) библиографског цитирања ${ }^{1}$ користи се у научним радовима из историје и других хуманистичких наука. Приручник Чикаі̄o сйила (The Chicago Manual of Style, у даљем тексту CMOS) ${ }^{2}$ представља упутство за коришћење овог стила. Објавио га je University of Chicago Press 1906. године. До данас је доживео 17 издања, од којих је последње објављено 2017. године. Спада у прве приручнике за цитирање и великим делом је допринео стандардизацији истраживачке методологије. CMOS jе доступан у штампаној и онлајн верзији, међутим, без плаћања годишње претплате, немогуће му је приступити.

Приручник наводи два основна начина систематизације извора: Notes and Bibliography style (стил хуманистичких наука) и Author-date system (систем аутор-датирање). Избор између ова два начина често зависи од личних склоности, али још чешће од врсте тема и природе извора који се наводе, као и од захтева оних који прописују употребу једног од њих (издавачи, факултети, уредништво часописа итд.). Оба стила су веома слична

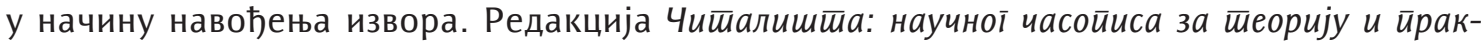
су библиошекарсивва, у складу са традицијом заступљеном у часописима са тематиком из библиотечко-информационе делатности у свету, определила се за Notes and Bibliography style (односно Humanities Style). Овај начин цитирања представља библиографску

\footnotetext{
1 Рад је прерађена и допуњена верзија текстова: Драгана Сабовљев, „Чикаго стил библиографског цитирања“, Паниевачко чиша-

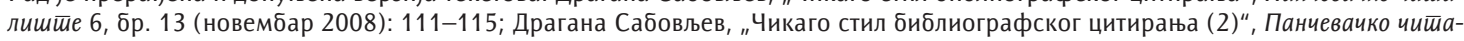

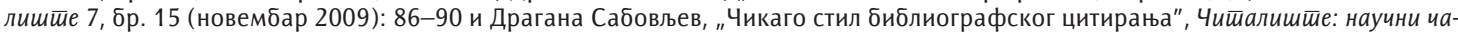
сойис за шеорију и ираксу библиошекарсшива, преузето 16. 5. 2018, http://www.citaliste.rs/citaliste_files/sabovljev_cikago_stil.pdf.

${ }^{2}$ Chicago Manual of Style Online, preuzeto 17. 5. 2018, http://www.chicagomanualofstyle.org/home.html.
} 
јединицу у фуснотама и библиографији или списку коришћене литературе и извора. Веома је прилагодљив разноврсним информацијама и обрађује изворе које не предвиђају други стилови цитирања.

У овом тексту ће бити приказани начини цитирања публикација које се најчешће користе као референсна литература у научном раду.

Пре тога, нужно је дати неке напомене: као што је већ поменуто, „Notes and Bibliography систем радије користе они који се баве хуманистичким наукама - укључујући књижевност, историју и уметности. У овом систему, извори се наводе у фуснотама или енднотама означеним редним бројевима. Свака од њих има одговарајући редни број у тексту (superscript). Извори се такође наводе у библиографији на крају рада.."

Електронски извори (ако поседују довољно елемената за навођење) третирају се као штампани и треба их наводити слично њиховим штампаним облицима, али са URL додатком. Неки часописи, издавачи, или одређене дисциплине, захтевају и датум приступа извору те га треба навести пре веб-адресе.

Извори се наводе језиком и писмом коришћене публикације. Уколико је већина извора ћирилична и на српском и другим језицима који користе ово писмо, у библиографији, или литератури и изворима на крају рада, наводи се азбучним редоследом. Ако су латинични и/ или на страним језицима - абецедним. ${ }^{4}$

Истоветне фусноте које следе изворе цитиране у целини требале би да се скраћују где год је то могуће (ако су, нпр, 1. и 3. фуснота идентичне, 3. се скраћује на следећи начин: Презиме, Наслов или „Нав. дело“, страна).

Фусноте које се састоје од неколико извора који доказују једну чињеницу требало би одвојити тачкама-зарезима. Тачком-зарезом одвајају се и два места издања, два издавача итд.

Вишеструки наводи једне фусноте требали би да упућују на претходну (нпр. ред. бр. Видети фусноту број... изнад).

Када се ради о анонимном делу, фуснота и библиографска јединица почињу насловом рада.

Ibid. или "Исто“ (уколико се ради о ћириличном извору, увек би требало користити „Исто“) користи се на месту имена аутора, наслова и онолико информација које су идентичне онима у претходној фусноти (нпр. ред. бр. Ibid. (Исто), стране). Не може се користити уколико претходна фуснота наводи више од једног дела.

У фуснотама се наводе само страна/стране из којих је преузет цитат, али у библиографији се морају навести све стране (од-до) на којима се налази целокупни текст, поглавље из књиге итд. За директно цитирање извора без броја страна, требало би користити име поглавља, број пасуса, или неку другу организациону поделу рада.

Требало би избегавати цитате преузете из секундарних извора јер је основна идеја да истраживачи сами проуче рад који цитирају. Уколико оригинално дело није доступно, морају се навести и примарни и секундарни извори (нпр. ред. бр. Име, презиме, Наслов (Место издања: Издавач, година), страна, цитирано у Име, презиме, „Наслов текста“, Наслов иасойиса број, свеска (датум или само година): страна). ${ }^{5}$

\footnotetext{
3 "Chicago-Style Citation Quick Guide", in Chicago Manual of Style Online, preuzeto 17. 5. 2018, http://www.chicagomanualofstyle. org/tools_citationguide.html.

${ }^{4}$ Неки часописи, попут Чишалишеша, да би испунили услове за стицање више категорије у процесу категоризације часописа коју спроводи Министарство просвете, науке и технолошког развоја Републике Србије, одступају од овог правила, па се тако списак литературе и извора на крају рада пише абецедним редом, латиницом, без обзира на писмо публикације, изузев оних писаних на језицима који не употребљавају латинично писмо (руски, македонски, бугарски, на пример), док се фусноте наводе језиком и писмом публикације или извора.

5 Делимично преузето из: Williams Library, “Citing Your Sources: Chicago: Notes", preuzeto 17. 5. 2018, http://library.williams. edu/citing/styles/chicago1.php. Дате су напомене прилагођене српским језичким нормама и уобичајеним начинима навођења.
} 


\section{Примери навођења извора}

\section{- навођење књиї:}

\section{1 aуйор:}

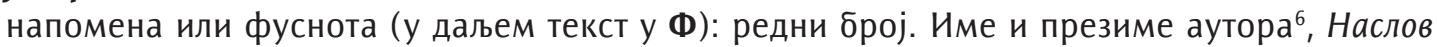
књиїе (Место издања: Издавач, година), страна ${ }^{8}$.

1. Бранко В. Радичевић, Приче о животињама (Београд: Српска књижевна задруга, 1991), 26.

Уколико се у раду овај извор понавља, наводи се на следећи начин: Радичевић, Приче 0 живошинама, или Нав. дело ${ }^{9}, 15$.

библиографија (у даљем тексту Б): редни број10. Презиме, име аутора. Наслов књиіе. Место издања: Издавач, година.

22. Радичевић, Бранко В. Приче о живошиињама. Београд: Српска књижевна задруга, 1991.

\section{2 и 3 ауйора:}

Ф: редни број. Име и презиме и име и презиме аутора, Наслов књиіе (Место издања: Издавач, година), страна.

2. Гордана Стокић Симончић и Жељко Вучковић, Уӣрављање библиошекама у gобу знања (Источно Сарајево: Градска библиотека, 2007), 36-42.

Уколико се у раду овај извор понавља, наводи се на следећи начин: Стокић Симончић и Вучковић, Уйрављање библиошекама..., или Нав. дело, 57.

Б: Презиме, име и име и презиме аутора. Наслов књиіе. Место издања: Издавач, година.

Стокић Симончић, Гордана ${ }^{11}$ и Жељко Вучковић. Уйрављање библиоиекама у gобу знања. Источно Сарајево: Градска библиотека, 2007.

\section{4 или више аутиора:}

Ф: редни број. Име и презиме аутора и др. ${ }^{12}$, Наслов књиіе (Место издања: Издавач, година), страна.

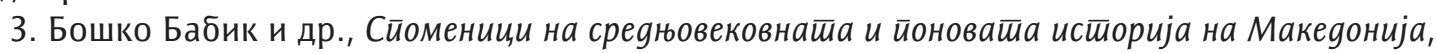

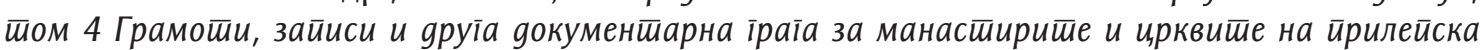
области, ур. Владимир Мошин (Скопје; Прилеп: Институт за истражување на старословенската култура, 1981), 254.

Уколико се у раду овај извор понавља, наводи се на следећи начин: Бабик и др., Сйомениии..., или Нав. дело, 278.

Б: Презиме, име, име и презиме, име и презиме, име и презиме и име и презиме аутора. Наслов књиїе. Место издања: Издавач, година.

\footnotetext{
${ }^{6}$ Ако аутор има иницијал, у фусноти се наводи између имена и презимена, а у библиографији иза имена, ако је први наведени аутор, а ако није, као и у фусноти.

7 Сваки стил цитирања, па тако и Чикаїо, има веома прецизно утврђена правила када се употребљавају знаци навода, када италик, а посебну пажњу би требало обратити на знаке интерпункције.

8 или стране, ако се наводи већи део текста

9 Уколико се наводи више радова једног аутора, не може се користити „Нав. дело“, јер се не зна на који рад се односи. У том случају, у скраћеном опису се пише наслов или део наслова.

10 Библиографске јединице у списку литературе и извора наводе се азбучним или абецедним редом, у зависности од језика и писма (видети фусноту 3 која говори о изузецима од овог правила), па ће описана јединица добити на овај начин и свој редни број.

11 У CMOS-у је предвиђено да и иза имена, а пре „и“ стоји запета (нпр. Grazer, Brian, and Charles Fishman. A Curious Mind: The Secret to a Bigger Life. New York: Simon \& Schuster, 2015.), међутим, ауторка је дала себи за право да то изостави у овом Упутству јер сматра да није у духу језичких и правописних правила и норми српског језика.

12 Ако је извор на страном језику, наведен латиничним писмом, користи се израз „еt al.“.
} 
Бабик, Бошко, Владимир Мошин, Славица Николовска, Загорка Расолкоска-Николовска, Лидија Славева и Радмила Угринова-Скаловска подготовиле ${ }^{13}$. Сйоменици на среgюовековна-

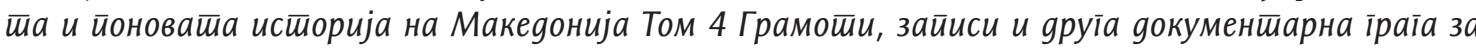

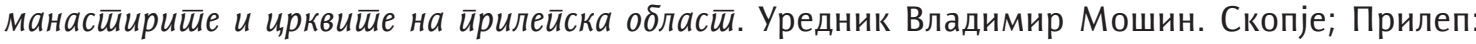
Институт за истражување на старословенската култура, 1981.

ӣримарна оgі̄оворносӣ уреgника, ӣревоgиоца или ӣриређивача, каgа није навеgен ауйор:

Ф: редни број. Име и презиме, ур., гл и одг. ур., прев., прир., Наслов књиїе (Место издања: Издавач, година), страна.

4. Gojko Tešić, prir., Citat Vinaver (Beograd: Kulturni centar Beograda, 2007), 235.

Уколико се у раду овај извор понавља, наводи се на следећи начин: Tešić, Citat Vinaver, или Nav. delo, 55.

Б: Презиме, име, ур., гл и одг. ур., прев., прир. Наслов књиіе. Место издања: Издавач, година.

Tešić, Gojko, prir. Citat Vinaver. Beograd: Kulturni centar Beograda, 2007.

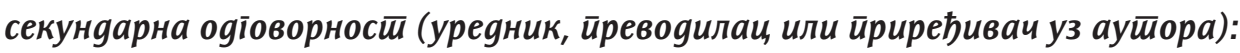

Ф: редни број. Име и презиме аутора, Наслов књиіе, ур., гл. и одг. ур., прев., прир. Име и презиме ${ }^{14}$ (Место издања: Издавач, година), страна.

5. Вилијам Шекспир, Маїбеш, прир. Владислава Гордић Петковић, прев. Светислав Стефановић (Београд: Завод за уџбенике и наставна средства, 2003), 23.

Б: Презиме, име аутора. Наслов књиіе. Уредник, Главни и одговорни уредник, Превео, Приредио Име и презиме. Место издања: Издавач, година.

Шекспир, Вилијам. Маїбеши. Приредила и пропратне белешке написала Владислава Гордић Петковић. Превео Светислав Стефановић. Београд: Завод за уџбенике и наставна средства, 2003.

\section{йоїлавље или неки gруїи gео књиїе:}

Ф: редни број. Име и презиме аутора, „Наслов поглавља“, у Наслов књиіе, прир., ур., ${ }^{15}$ Име и презиме (Место издања: Издавач, година), страна.

6. Гордана Стокић Симончић, Бојана Требињац и Драгана Сабовљев, „Основне карактеристике развоја књижне културе у Античкој Грчкој“, у Библиошека кроз време: Прилози ой-

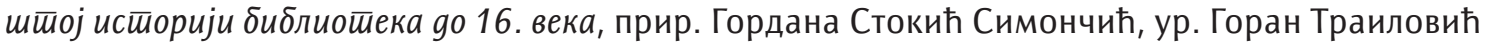
и Гордана Стокић Симончић (Пачево: Градска библиотека; Београд: Филолошки факултет, 2017), 32-33.

Уколико се у раду овај извор понавља, наводи се на следећи начин: Стокић Симончић, Требињац и Сабовљев, „Основне карактеристике...“ или Нав. дело, 25.

Б: Презиме, име аутора. „Наслов поглавља“. У Наслов књиіе, приредио/приредила, уредник Име и презиме, стране. Место издања: Издавач, година.

Стокић Симончић, Гордана, Бојана Требињац и Драгана Сабовљев. „Основне карактеристике развоја књижне културе у Античкој Грчкој“. У Библиошека кроз време: Прилози ойшйој истиорији библиошека gо 16. века, приредила Гордана Стокић Симончић, уредници Горан Траиловић и Гордана Стокић Симончић, 23-37. Пачево: Градска библиотека; Београд: Филолошки факултет, 2017.

\footnotetext{
13 Уколико публикација има до 10 аутора, CMOS прадвиђа да се у библиографији наведу сви. Ако их има више од 10, користи се формулација „и др.“ или „еt al.“, уколико је извор на страном језику.

14 Уколико има више лица која носе секундарну одговорност, наводе се сва.

15 Уколико је приређено издање, збирка или зборник, обавезно се наводи уредник или приређивач.
} 
йоїлавље ӣриређеної шома књиїе (у оgносу на ӣримарне изворе):

Ф: редни број. Име и презиме аутора, „Наслов поглавља“, у Наслов књиїе, ур. Име и презиме, том Наслова књиге, ур. Име и презиме (Место издања: Издавач, година), страна.

7. Quintus Tulius Cicero, "Handbook on Canvassing for the Consulship", in Rome: Late Republic and Principate, eds. Walter Emil Kaegi Ir. and Peter White, Vol. 2 University of Chicago Readings in Western Civilization, eds. John Boyer and Julius Kirshner (Chicago: University of Chicago press, 1986), 35.

Уколико се у раду овај извор понавља, наводи се на следећи начин: Cicero, “Handbook on Canvassing for the Consulship", или Nav. delo, 40.

Б: Презиме, име аутора. „Наслов поглавља“. У Наслов књиіе, уредник Име и презиме. Том Наслова књиіе, уредник Име и презиме, стране. Место издавања: Издавач, година. ${ }^{16}$

Cicero, Quintus Tulius. "Handbook on Canvassing for the Consulship". In Rome: Late Republic and Principate, edited by Walter Emil Kaegi Jr. and Peter White. Vol. 2 University of Chicago Readings in Western Civilization, edited by John Boyer and Julius Kirshner, 33-46. Chicago: University of Chicago press, 1986. Originalno objavljeno u Evelyn S. Shuckburg, trans., The Letters of Cicero, Vol. 1 (London: George Bell \& Sons, 1908).

\section{ӣреgїовор, увоgник, ӣоїовор:}

Ф: редни број. Име и презиме, предговор, уводник, поговор у Наслов књиіе, Име и презиме аутора (Место издања: Издавач, година), стране.

8. Neven Ušumović, pogovor u Alternativni vodič kroz Vavilon, Srđan V. Tešin (Zrenjanin: Gradska narodna biblioteka "Žarko Zrenjanin“, 2008), 152.

Уколико се у раду овај извор понавља, наводи се на следећи начин: Ušumović, pogovor u Alternativni vodič... или Nav. delo, 152.

Б: Презиме, име. Предговор, уводник, поговор у Наслов књиіе, Име и презиме аутора, стране. Место издања: Издавач, година.

Ušumović, Neven. Pogovor u Alternativni vodič kroz Vavilon, Srđan V. Tešin, 151-154. Zrenjanin: Gradska narodna biblioteka „Žarko Zrenjanin“, 2008.

\section{јеgинища из ирриручника:}

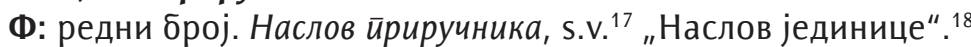

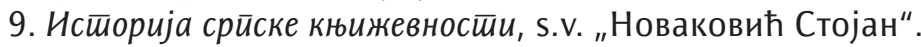

Б: Познате енциклопедије и речници се обично не наводе у библиографији, мада је много корисније и прегледније унети их. Наводе се, као и остали приручници, као књиге.

Деретић, Јован. Нсиоорија срйске књижевносиии. Београд: Требник, 1996.

елекирронска изgања књиїа - онлајн, е-books, или на неком gруїом меguјуму19:

(Ако је књига доступна у више формата, требало би навести ону верзију која је коришћена у раду, али се могу навести и други формати.)

Ф: редни број. Име и презиме аутора, Наслов књиїе (Место издања: Издавач, година), http://adresa.

\footnotetext{
16 Уколико је том оригинално издат негде другде, додаје се и: Оригинално објављено у Име, презиме, ур., Наслов, том (Место издавања: Издавач, година). Пример је преузет из текста The Chicago Manual of Style Online, "Chicago-Style Citation Quick Guide", preuzeto 23. 9. 2008, http://www.chicagomanualofstyle.org/tools_citationguide.html. Ово издање је из 2003. године и пружало је много више практичних примера него издање из 2017.

17 (лат. sub verbo - под)

18 За онлајн приручнике додати датум преузимања и веб-адресу.

19 Књигама које се консултују онлајн додаје се URL (енгл. Uniform Resource Locator) или назив базе података. За друге типове е-books, навести формат. Уколико немају пагинацију, у фусноти би требало навести наслов или број дела или поглавља, уколико постоји (или једноставно изоставити). - "Chicago-Style Citation Quick Guide", in Chicago Manual of Style Online, preuzeto 17. 5. 2018, http://www.chicagomanualofstyle.org/tools_citationguide.html.
} 
10. Бранислав Нушић, Аушооиоїрафија (Београд: Креативни центар, 2001), http://www. antikvarneknjige.com/elektronskeknjige/detail-item_39.

Уколико се у раду овај извор понавља, наводи се на следећи начин: Нушић, Ауш̄обиоїрафија, или Нав. дело.

Б: Презиме, име аутора. Наслов књиїе. Место издања: Издавач, година. http://adresa. Tакође доступно у штампаном облику, на CD-ROM, Kindle, итд.

Нушић, Бранислав. Ауш̄обиоїрафија. Београд: Креативни центар, 2001. http://www.antikvarneknjige.com/elektronskeknjige/detail-item_39. Такође доступно у штампаном облику.

Ф: Marsel Prust, Jedna Svanova ljubav, prevodilac Živojin Živojinović (Beograd: Laguna, 2018), poglavlje 4, Kindle.

Уколико се у раду овај извор понавља, наводи се на следећи начин: Prust, Jedna Svanova ljubav, или Nav. delo, poglavlje 4.

Б: Prust, Marsel. Jedna Svanova ljubav. Prevodilac Živojin Živojinović. Beograd: Laguna, 2018. Kindle.

\section{- навођење paga у иасойucy:}

pag у иасойису у шйамйаном облику (јеgан ауйор):

Ф: редни број. Име и презиме аутора, „Наслов текста“, Наслов иасойиса година излажења, број, свеска (година): страна/стране, DOI број20.

14. Владислава Гордић Петковић, „Библиотека у сопственој соби: ауторке, јунакиње и

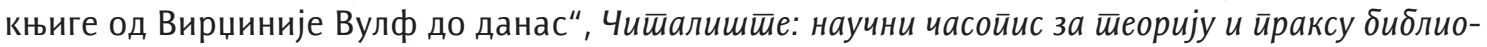

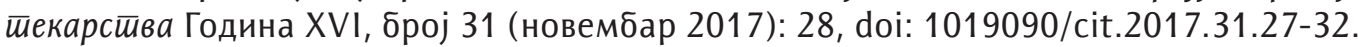

Уколико се у раду овај извор понавља, наводи се на следећи начин: Гордић Петковић, „Библиотека у сопственој соби...” или Нав. дело: 30.

Б: Презиме, име. „Наслов текста“. Наслов иасойиса година излажења, број, свеска (година): стране од-до (без стр.). DOI број.

Гордић Петковић, Владислава. „Библиотека у сопственој соби: ауторке, јунакиње и књиге

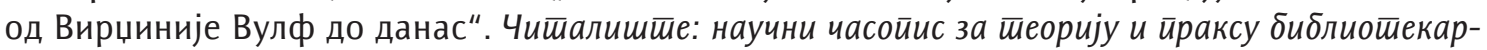
сивва Година XVI, број 31 (новембар 2017): 27-32. doi: 1019090/cit.2017.31.27-32.

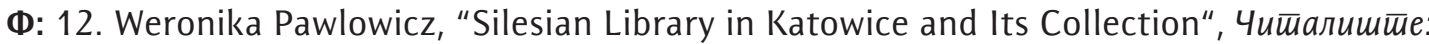
научни иасойис за шееоију и ираксу библиошекарстива Година XVI, број 31 (новембар 2017): 34, doi: 1019090/cit.2017.31.33-37.21

Уколико се у раду овај извор понавља, наводи се на следећи начин: Pawlowicz, “Silesian Library..." или Nav delo: 34.

Б: Pawlowicz, Weronika. "Silesian Library in Katowice and Its Collection". Чишалишие:

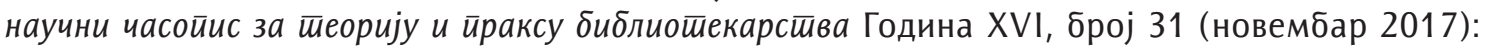
33-37. doi: 1019090/cit.2017.31.33-37.

\section{pag у иасоӣucy (2 или 3 ауйора):}

Ф: редни број. Име презиме и име и презиме, „Наслов текста“, Наслов иасойиса година излажења, број, свеска (година): страна, DOI број.

10. Цветана Крстев и Агата Савари, „Игре са полилексичким јединицама за боље повези-

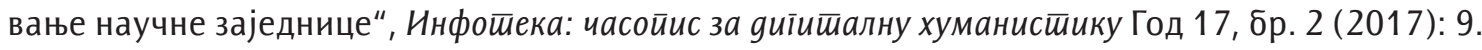

\footnotetext{
20 Нису увек сви подаци, попут године, броја или свеске доступни, многи часописи немају DOI, па се наводе они подаци који постоје - остали се изостављају. Велики број чланака у часопису поседује DOI (Digital Object Identifier). Њега чини cтални URL који почиње https://doi.org/. CMOS препоручује да се наведе овај URL радије него она веб-адреса на којој се налази часопис (О навођењу радова у електронским часописима биће речи у даљем тексту).

21 Овај текст је занимљив јер представља комбинацију два језика и писма те се, приликом цитирања, наводе оба.
} 
Уколико се у раду овај извор понавља, наводи се на следећи начин: Крстев и Савари, „Игре са полилексичким јединицама...” или Нав. дело: 15.

Б: Презиме, име и (или and - уколико је рад на страном језику) име и презиме. „Наслов текста". Наслов иасойиса година излажења, број, свеска (година): стране. DOI број.

Крстев, Цветана и Агата Савари. „Игре са полилексичким јединицама за боље повезивање

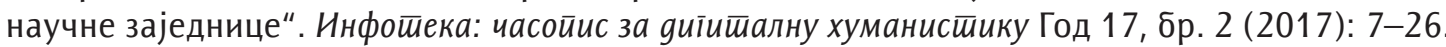

\section{pag у иасойису (4 и вище ауйора):}

Ф: редни број. Име и презиме и др., (et al., за радове на страним језицима), „Наслов текста“, Наслов иасойиса година излажења, број, свеска (година): страна, DOI број.

6. Loriene Roy et al., "The European Conference on Information Literacy: An International Research-Practice Nexus", College and Research Libraries News 78 (3) (2017): 132.

Уколико се у раду овај извор понавља, наводи се на следећи начин: Roy et al., "The European Conference on Information Literacy..." или Nav. delo: 133.

Б: Презиме, име, име и презиме, име и презиме и (или and - ако је рад на страном језику) име и презиме 22. „Наслов текста“. Наслов иасойиса година излажења, број, свеска (година): стране. DOI број.

Roy, Loriene, Serap Kurbanoğlu, Diane Mizrachi and Sonja Špiranec. "The European Conference on Information Literacy: An International Research-Practice Nexus". College and Research Libraries News 78 (3) (2017): 131-134.

\section{pag у онлајн часойису или у оном који има и шйамйану и елекйронску верзију:}

Без обзира да ли има једног или више аутора, рад се наводи као претходно описани примери, али му се додају датум преузимања и веб-адреса са које је преузет.

Ф: редни број. Име и презиме аутора, „Наслов текста“, Наслов иасойиса година излажења, број, свеска (година): страна/стране, датум преузимања, веб-адреса.

3. Добрила Бегенишић, „Библиотекарство и лингвистика: интердисциплинарне везе“, Гласник Нароgне библиошеке Србије Година XVI, бр. 19 (2017): 39, преузето 20. 5. 2018, https:// www.nb.rs/view_file.php?file_id=5589.

Уколико се у раду овај извор понавља, наводи се на следећи начин: Бегенишић, „Библиотекарство и лингвистика..." или Нав. дело: 39.

Б: Презиме, име. „Наслов текста“. Наслов иасойиса година излажења, број, свеска (година): стране од-до (без стр.). Преузето датум. Веб-адреса.

Бегенишић, Добрила. „Библиотекарство и лингвистика: интердисциплинарне везе“. Гласник Нароgне библиошеке Србије Година XVI, бр. 19 (2017): 37-45. Преузето 20. 5. 2018. https://www.nb.rs/view_file.php?file_id=5589.

\section{чланак у йойуларном иасойису или новинама (у шйамйаном облику или онлајн):}

По CMOS-y, чланци из популарних часописа, новина (у штампаном облику или онлајн), блогови и слично, цитирају се на исти начин. Пагинација, ако је има, може се навести у фусноти, али се изоставља из библиографије. Уколико се чланак наводи из онлајн извора, уноси се веб-адреса или назив базе података.

Ф: редни број. Име и презиме аутора, „Наслов текста“, Наслов иасойиса, датум излажења, страна, рубрика, веб-адреса.

13. Предраг Урошевић, „Зима авганистанског задовољства“, Полишиикин Забавник, 18. 9. 2009, 14.

22 Радови у часописима често имају више аутора. Ако их је четворо или више, у библиографији се наводе до 10, а уколико их је више од 10, наводи се првих 7, уз „и др.“ или „еt al.". 
Уколико се у раду овај извор понавља, наводи се на следећи начин: Урошевић, „Зима авганистанског задовољства“ или Нав. дело.

Б: Презиме, име аутора. „Наслов текста“. Наслов иасойиса, датум излажења, рубрика, веб-адреса. Урошевић, Предраг. „Зима авганистанског задовољства“. Полишиикин Забавник, 18. 9. 2009.

Ф: 1. Neil Gaiman, "Why our future depends on libraries, reading and daydreaming”, The Guardian, Tue 15 Oct 2013, https://www.theguardian.com/books/2013/oct/15/neil-gaiman-futurelibraries-reading-daydreaming.

Уколико се у раду овај извор понавља, наводи се на следећи начин: Gaiman, “Why our future depends on libraries, reading and daydreaming" или Nav. delo.

Б: Gaiman, Neil. "Why our future depends on libraries, reading and daydreaming". The Guardian, Tue 15 Oct 2013. https://www.theguardian.com/books/2013/oct/15/neil-gaiman-futurelibraries-reading-daydreaming.

Ф: 3. Peca Popović, „Otmenonepristajanjena osrednjost“ "Blic,21.5.2018, Kultura, www.blic.rs/ kultura/vesti/peca-popovic-otmeno-nepristajanje-na-osrednjost/z3dk6px. ${ }^{23}$

Уколико се у раду овај извор понавља, наводи се на следећи начин: Popović, „Otmeno nepristajanje na osrednjost".

Б: Popović, Peca. „Otmeno nepristajanje na osrednjost". Blic, 21. 5. 2018. Kultura. www.blic. rs/kultura/vesti/peca-popovic-otmeno-nepristajanje-na-osrednjost/z3dk6px.

Ф: 7. Zrznacka, „Preporuka Kluba knjige Gradske narodne biblioteke ,Žarko Zrenjanin'“ , Čitalačkaznačka-blog, 3. april 2018, https://zrznacka.wordpress.com/2018/04/03/preporuka-klubaknjige-gradske-narodne-biblioteke-zarko-zrenjanin/.

Уколико се у раду овај извор понавља, наводи се на следећи начин: Zrznacka, „Preporuka Kluba knjige....".

Б: Zrznacka. „Preporuka Kluba knjige Gradske narodne biblioteke ,Žarko Zrenjanin”“. Čitalačka značka, blog, 3. april 2018. https://zrznacka.wordpress.com/2018/04/03/preporuka-klubaknjige-gradske-narodne-biblioteke-zarko-zrenjanin/.

\section{йриказ или рецензија књиїе у часойису:}

Ф: редни број. Име и презиме, „Наслов текста“, приказ Наслов књиїе, Име и презиме аутора, Наслов иасойиса, датум, година, страна.

15. Бранка Драгосавац, "Сага о Драшкоцијевима“, приказ Саїа о Драшкоиијевима, Десан-

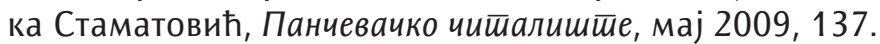

Уколико се у раду овај извор понавља, наводи се на следећи начин: Драгосавац, „Сага о Драшкоцијевима“, 137.

Б: Презиме, име. „Наслов текста“. Приказ Наслов књиіе, Име и презиме аутора. Наслов иасойиса, датум, година.

Драгосавац, Бранка. „Сага о Драшкоцијевима“. Приказ Саїа о Драшкоиијевима, Десанка

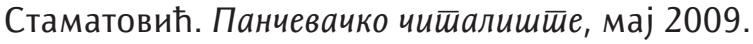

\section{- pag из базе йоgайака у full text-y:}

Наводи се као претходно описани пример, али се додаје веб-адреса часописа или друге публикације, у зависности одакле је рад преузет.

\section{- навођење инйервјуа:}

Ф: Име и презиме, „Наслов интервјуа“, Наслов иасойиса, новина, веб-сйраниие, итд., интервју водио/водила (уколико је потписан аутор интервјуа), датум, веб-адреса (уколико је интервју објављен онлајн).

\footnotetext{
23 Уколико се овај рад наведе из штампаног издања, редослед података је исти, али се изоставља веб-адреса.
} 
19. Dragan Tomić, "Osnove programiranja su nova pismenost 21. veka", Blic, 3. 3. 2018, https://www.blic.rs/vesti/ekonomija/osnove-programiranja-su-nova-pismenost-21-veka/ j2ky05y.

Уколико се у раду овај извор понавља, наводи се на следећи начин: Tomić, „Osnove programiranja..."

Б: Презиме, име. „Наслов интервјуа“. Наслов иасойиса, новина, веб-сйраниие, итд. Интервју водио/водила (уколико је потписан аутор интервјуа). Датум. веб-адреса (уколико је интервју објављен онлајн).

Tomić, Dragan. „Osnove programiranja su nova pismenost 21. veka”. Blic, 3. 3. 2018. https:// www.blic.rs/vesti/ekonomija/osnove-programiranja-su-nova-pismenost-21-veka/j2ky05y.

\section{- навођење необјављене маїисйарске йезе или докйорске gисерйације:}

Ф: редни број. Иницијал имена. презиме аутора, „Наслов тезе или дисертације“ (магистарска теза или докторска дис., назив факултета, година), стране. ${ }^{24}$

18. Н. Идризовић, „Патријаршијска библиотека Српске православне цркве: 1706-2006“ (докторска дис., Филолошки факултет, 2016), 155-160.

Уколико се у раду овај извор понавља, наводи се на следећи начин: Идризовић, „Патријаршијска библиотека...“" или Нав. дело, 144.

Б: Презиме, иницијал имена. „Наслов тезе или дисертације“. Магистарска теза или докторска дис., назив факултета, година.

Идризовић, Н. "Патријаршијска библиотека Српске православне цркве: 1706-2006“. Докторска дис., Филолошки факултет, 2016.

- pag изложен на сйручном скуйу или конференцији:

Ф: редни број. Име и презиме, „Наслов рада“ (рад представљен на Назив скупа или конференције, Град, Држава, датум одржавања, година)..$^{25}$

19. Барбара Шлајнхаген, „Гвожђе се кује док је вруће: лобирање за библиотеке у доба дигиталне трансформације“ (рад представљен на О чему говорим када говорим о библиотекама: заговарање, промовисање, лобирање, Београд, Србија, 13-15. децембар 2017).

Уколико се у раду овај извор понавља, наводи се на следећи начин: Шлајнхаген, „Гвожђе се кује док је вруће...".

Б: Презиме, име аутора. „Наслов рада“. Рад представљен на Назив скупа или конференције, Град, Држава, датум одржавања, година.

Шлајнхаген, Барбара. „Гвожђе се кује док је вруће: лобирање за библиотеке у доба дигиталне трансформације". Рад представљен на О чему говорим када говорим о библиотекама: заговарање, промовисање, лобирање, Београд, Србија, 13-15. децембар 2017.

CMOS и у издању из 2017. године предвиђа навођење мултимедијалних докумената, музичких композиција, партитура, звучних или видео-записа, дела визуелних уметности, али је приметно да се мењају медији њиховог чувања. У овом делу рада биће поновљени примери из претходног Упутства због редоследа навођења података, али би требало узети у обзир чињеницу да се они све више налазе на интернету и да се уз њихове описе најчешће додају и датум преузимања и веб-адреса.

\footnotetext{
24 Уколико се рад наводи из базе података или неког другог електронског извора, додају се назив базе, датум преузимања и/или веб-адреса.

25 Исто.
} 


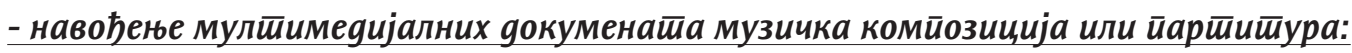

Ф: Име и презиме аутора, „Наслов композиције“ у Наслов йубликације, ур. Име и презиме, стране (Место издања: Издавач, година).

20. Стеван Стојановић Мокрањац, „Ал' је леп овај свет“ у Музичка кулешура 6, ур. Тамара Поповић Новаковић, 22 (Београд: Завод за уџбенике, 2009).

Уколико се у раду овај извор понавља, наводи се на следећи начин: Мокрањац, „Ал' је леп овај свет“", 22.

Б: Презиме, име аутора. „Наслов композиције“. У Наслов йубликације, уредник Име и презиме, стране. Место издања: Издавач, година.

Стојановић Мокрањац, Стеван. „Ал' је леп овај свет“. У Музичка кулеиура 6, уредник Тамара Поповић Новаковић, 22. Београд: Завод за уџбенике, 2009.

\section{- звучни зайис:}

Ф: Име и презиме аутора, Наслов зайиса, продуцентска кућа - медиј.

21. Carlos Santana, Supernatural, BMG Arista-CD.

Уколико се у раду овај извор понавља, наводи се на следећи начин: Santana, Supernatural.

Б: Презиме, име аутора. Наслов зайиса. Име продуцентске куће, издавача - медиј.

Santana, Carlos. Supernatural. BMG Arista-CD.

По CMOS-у, звучни записи се наводе под именом композитора, писца или друге особе задужене за садржај. Име извођача се може додати после наслова. Продуцентска кућа и број записа су обично довољни да се запис идентификује.

\section{- вugeo зайuc:}

Ф: редни број. Наслов филма, медиј, редитељ Име и презиме (Место издања: Издавач, година).

22. Hadersfild, DVD, reditelj Ivan Živković (Beograd: Eye to Eye, 2007).

Уколико се у раду овај извор понавља, наводи се на следећи начин: Hadersfild.

Б: Наслов филма. Редитељ Име и презиме. Место издања: Издавач, година. Медиј. Hadersfild. Reditelj Ivan Živković. Beograd: Eye to Eye, 2007. DVD.

CMOS каже да су подаци за видео записе углавном слични записима за књиге, са додатком у виду податка о врсти медија.

\section{- gокуменйи извршних влаgиних орїана:}

Ф: редни број. Име министарства, Наслов шекстиа, Име и презиме аутора (Место издања: Издавач, година), преузето датум, http://adresa. ${ }^{26}$

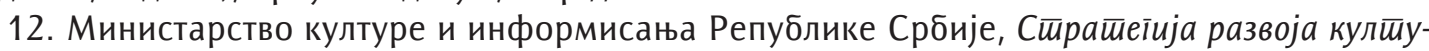
ре Рейублике Србије og 2017. gо 2027., преузето 15. 5. 2018, http://www.kultura.gov.rs/docs/ dokumenti/predlog-strategije-razvoja-kulture-republike-srbije-od-2017--do-2027-/-predlogstrategije-razvoja-kulture-republike-srbije-od-2017--do-2027-.pdf.

Уколико се у раду овај извор понавља, наводи се на следећи начин: Министарство културе и информисања Републике Србије, Сш̄рат̄еїија развоја...

Б: Име министарства. Наслов шекстиа. Име и презиме аутора. Место издања: Издавач, година. Преузето датум. http://adresa.

Министарство културе и информисања Републике Србије. Сйрайеїија развоја кулйуре Peйублике Србије og 2017. go 2027. Преузето 15. 5. 2018. http://www.kultura.gov.rs/docs/dokumenti/predlog-strategije-razvoja-kulture-republike-srbije-od-2017--do-2027-/-predlog-strategije-razvoja-kulture-republike-srbije-od-2017--do-2027-.pdf.

\footnotetext{
${ }^{26}$ Као и код осталих примера, наводе се само они подаци који постоје у документу. Код владиних докумената често не постоје подаци о аутору, месту издања или издавачу, а пошто се прописи углавном објављују у Службеном іласнику Рейублике Србије, логичније их је наводити као радове из часописа, што ће показати следећи пример.
} 
Ф: 22. „Zakon o bibliotečko-informacionoj delatnosti“, Službeni glasnik RS broj 52 (2011), član 3., preuzeto 26. 9. 2016, https://www.nb.rs/view_file.php?file_id=3047.

Уколико се у раду овај извор понавља, наводи се на следећи начин: „Zakon o bibliotečkoinformacionoj delatnosti“" član 22, stav 2 .

Б: „Zakon o bibliotečko-informacionoj delatnosti“. Službeni glasnik RS broj 52 (2011). Preuzeto 26. 9. 2016. https://www.nb.rs/view_file.php?file_id=3047.

\section{- навођење веб-ситраница:}

Овде се не може наћи прецизан модел навођења јер извори са интернета често немају потребне податке за цитирање. Изузетак представљају електронски часописи који имају све неопходне податке. Начин њиховог навођења је описан у тексту. На веб-страницама се најчешће не могу пронаћи имена аутора текстова, па чак ни наслови, нејасно је и коме припада сајт. Уколико елементи постоје, наводе се као текстови из часописа, са додатком адресе. Ако елемената за навођење нема, најчешће се наводе само назив странице, датум преузимања и веб-адреса.

По CMOS-y, „Често је довољно само описати веб-страницу или други садржај у тексту (,По подацима од 1. маја 2017, почетна страница Јејл универзитета наводи...'). Уколико је потребно формалније цитирање, оно се наводи на начин дат у примерима. За извор који не поседује датум објављене публикације или информације, уноси се датум приступа, односно преузимања"27.

Ф: редни број. Име организације, „Наслов текста“, име власника сајта, адреса постављања или нове верзије, уколико је нема, датум преузимања, http://adresa.

25. IFLA Cataloguing Section, "IFLA Library Reference Model (LRM)", IFLA, Last update 14 March 2018, http://www.ifla.org/VII/s8/index.htm.

Уколико се у раду овај извор понавља, наводи се на следећи начин: IFLA Cataloguing Section, LRM.

Б: Име организације. „Наслов текста“. Име власника сајта. Адреса постављања или нове верзије, уколико је нема, датум преузимања, http://adresa.

IFLA Cataloguing Section. "IFLA Library Reference Model (LRM)". IFLA. Last update 14 March 2018. http://www.ifla.org/VII/s8/index.htm.

Ф: 9. Катедра за библиотекарство и информатику, "Историјат“, Филолошки факултет Универзитета у Београду, преузето 9. 10. 2017, http://www.fil.bg.ac.rs/lang/sr/katedre/ bibliotekarstvo-i-informatika/istorijat/.

Уколико се у раду овај извор понавља, наводи се на следећи начин: Катедра за библиотекарство и информатику, "Историјат“.

Б: Катедра за библиотекарство и информатику. „Историјат“. Филолошки факултет Универзитета у Београду. Преузето 9. 10. 2017. http://www.fil.bg.ac.rs/lang/sr/katedre/ bibliotekarstvo-i-informatika/istorijat/.

Ф: 18. Pesnička štafeta 2018., "Izložba Pesnička štafeta - jedinstveno kulturno nasleđe", Gradska narodna biblioteka "Žarko Zrenjanin“, video zapis, objavljeno 17. 5. 2018, https:// www.youtube.com/watch?v=0_e3AJZQF48\&t=28s.

Уколико се у раду овај извор понавља, наводи се на следећи начин: Pesnička štafeta 2018.

Б: Pesnička štafeta 2018. „Izložba Pesnička štafeta - jedinstveno kulturno nasleđe“. Gradska narodna biblioteka „Žarko Zrenjanin“. Video zapis. Objavljeno 17. 5. 2018. https://www. youtube.com/watch?v=0_e3AJZQF48\&t=28s.

\footnotetext{
27 "Chicago-Style Citation Quick Guide".
} 


\section{- саgржаји на друшишвеним мрежама:}

Пошто је комуникација на друштвеним мрежама постала незаобилазни сегмент свакодневног живота, CMOS предвиђа навођење и оваквих извора: „Навођење садржаја који се дели на друштвеним мрежама обично се ограничава на сам текст (,Твит Конана О'Брајена је уобичајено безизражајан: ,У част дана планете Земље рециклирам своје твитове' (@СоnanOBrien, April 22, 2015)'). Може се додати напомена уколико је неопходно формалније навођење. У ретким случајевима захтева се и унос у списак коришћене литературе и извора. На месту наслова би требало навести првих 160 карактера поста (објаве) ${ }^{\mu 28}$.

Ф: Име и презиме аутора, „Наслов поста или део текста“, Назив друштвене мреже, датум преузимања или објављивања, веб-адреса.

Ф: Бранко Јевђић, „Библиотека Лазаревац, ,Одржан стручни скуп под називом ,Библиотеке - центри знања о ЕУ'“, Фејсбук, 21. 5. 2018, https://www.facebook.com/groups/ $171491692895266 /$.

Уколико се у раду овај извор понавља, наводи се на следећи начин: Јевђић, „Библиотека Лазаревац..."

Б: Презиме, име аутора. „Наслов поста или део текста“. Назив друштвене мреже, датум преузимања или објављивања, веб-адреса.

Јевђић, Бранко. „Библиотека Лазаревац, ,Одржан стручни скуп под називом ,Библиотеке - центри знања о ЕУ'“. Фејсбук, 21. 5. 2018. https://www.facebook.com/ groups/171491692895266/.

Ф: Vladimir Arsenić (vladimirarsenic1972), "\#gnbzarkozrenjanin \#zivebiblioteke“, Instagram fotografija, 19. 5. 2018, https://www.instagram.com/p/Bi-NETII6N5LAGn9x/BWvfwVCg ZOkTWN3pq5yk0/?hl=sr.

Уколико се у раду овај извор понавља, наводи се на следећи начин: Arsenić, "\#gnbzarkozrenjanin...".

Б: Arsenić, Vladimir (vladimirarsenic1972). „\#gnbzarkozrenjanin \#zivebiblioteke“. Instagram fotografija, 19. 5. 2018. https://www.instagram.com/p/Bi-NETIl6N5LAGn9xJBWvfwVCgZOkT WN3pq5yk0/?hl=sr.

\section{- лична комуникација:}

„Лична комуникација, укључујући имејл, смс, поруке послате преко друштвених мрежа, у раду се наводи само у фусноти, веома ретко се уноси у библиографију"29.

Ф: редни број. Име и презиме, е-mail, смс, Фејсбук, Месинџер, Вајбер, WhatsApp... порука аутору, датум.

28. Ivan Stojanović, Mesindžer poruka autorki, 7. 12. 2017.

\section{Закључна разматрања}

Као што се може приметити из новог Упутства, Чикаго стил библиографског цитирања претрпео је значајне промене у односу на претходна издања. Много више пажње се поклања електронским изворима и записима на друштвеним мрежама. То је последица развоја информационо-комуникационих технологија и утицаја медија на све сегменте живота, па и на научноистраживачки рад. Овде се може поставити питање да ли су овакви записи релевантни или довољно поуздани извори на које се може позивати у текстовима који претендују да буду оригинални научни, прегледни, или бар стручни радови. Одговор би могао бити да некада нема другачијег начина да се приступи оригинално објављеном садржају. То је био 
случај и у овом раду, у околностима да је приступ The Chicago Manual of Style Online ограничен и да не функционише ни free trial на 30 дана. Било је неопходно прикупити информације и коментаре из различитих извора да би се формирало Упутство за његово коришћење на српском језику.

Оно што је такође приметно је да се велика пажња поклања скраћивању извора у фуснотама, уколико се они понављају више пута у тексту. 3бог тога је и у овом раду, уз сваки пример навођења, понуђен пример сажимања података.

У Упутству се свесно одступило од три правила наведена у CMOS-у, у издању из 2017. године:

1. Ауторка сматра да није у духу српског језика, нити важећих језичких и правописних норми да после презимена аутора, а пре „и“ (када је у питању више аутора, независно од тога да ли се наводи монографска или рад из серијске публикације) унесе запета/зарез те га је изоставила.

2. У случају скраћивања већ понуђених извора, независно да ли се ради о књизи или раду у часопису, после целовитог или делимично наведеног наслова, или формулације „Нав. дело“, CMOS препоручује запету/зарез пре навођења пагинације. Ауторка сматра да би било прегледније да се после навођења књиге употреби зарез/запета пре пагинације, а при навођењу рада у часопису две тачке (:) јер се тиме разграничава врста извора која се наводи у скраћеном облику.

3. При цитирању електронских извора, за разлику од претходних издања, CMOS из 2017. не инсистира на датуму преузимања, односно приступања, него на датуму постављања, унапређивања, промена садржаја веб-стране итд. Ова препорука је дословно и доследно пренета и у овом раду. Међутим, као што је речено у Уводним напоменама, поједини издавачи или редакције часописа инсистирају да се датум унесе. Разлог је тај што се веб-странице често мењају и допуњују те је навођење датума преузимања и оправдање аутору да је, у тренутку када је приступио одређеном садржају, он изгледао или гласио тачно онако како га је употребио у свом тексту. Уз измену редоследа навођења, тј. да се датум преузимања наводи пре веб-адресе (за разлику од претходног Упутства да се наводи у заградама на крају библиографског описа и после адресе), редакција Чишалишеша моли ауторе да ипак наведу датум када су преузели неки садржај (формулација: Преузето датум, веб-адреса).

Сврха овог текста је да се помогне ауторима да савладају Чикаго стил библиографског цитирања, у Notes and Bibliography (односно у Humanities Style-y). Модерна техника и у овом смислу је изашла у сусрет ауторима. Наиме, све чешће се појављују софтвери који задате податке конвертују у библиографске јединице у литератури, напоменама и фуснотама. Ко је имао прилике да ради у новијим верзијама ворда нпр., такође може да се увери да је принцип цитирања и конвертовања података умногоме олакшан.

Чикаго стил библиографског цитирања преузима примат у области научноистраживачког рада у хуманистичким наукама. У Акту о уређивању часописа Министарства за науку и технолошки развој Републике Србије ${ }^{30}$ наведен је као један од стилова које подржавају водеће међународне базе које су намењене вредовању, као и Српски цитатни индекс. Тиме је потреба за упознавањем правила која прописује већа.

${ }_{30}$ Министарство просвете, науке и технолошког развоја Републике Србије, „Акт о уређивању научних часописа”, преузето 14. 7. 2016, http://www.ceon.rs/images/pdf/akt_o_uredjivanju_casopisa.pdf. 


\title{
Литература и извори:
}

1. "Chicago-Style Citation Quick Guide". In The Chicago Manual of Style Online. Preuzeto 23. 9. 2008. http://www.chicagomanualofstyle.org/tools_citationguide.html.

2. Chicago Manual of Style Online. Preuzeto 17. 5. 2018. http://www.chicagomanualofstyle.org/home.html.

3. "Chicago-Style Citation Quick Guide". In Chicago Manual of Style Online. Preuzeto 17. 5. 2018. http:// www.chicagomanualofstyle.org/tools_citationguide.html.

4. Ministarstvo prosvete, nauke i tehnološkog razvoja Republike Srbije. „Akt o uređivanju naučnih časopisa”. Preuzeto 14. 7. 2016. http://www.ceon.rs/images/pdf/akt_o_uredjivanju_casopisa.pdf.

5. Sabovljev, Dragana. „Čikago stil bibliografskog citiranja“. Pančevačko čitalište 6, br. 13 (novembar 2008): 111-115.

6. Sabovljev, Dragana. „Čikago stil bibliografskog citiranja (2)“. Pančevačko čitalište 7, br. 15 (novembar 2009): 86-90.

7. Sabovljev, Dragana. „Čikago stil bibliografskog citiranja”. Čitalište: naučni časopis za teoriju i praksu bibliotekarstva. Preuzeto 16. 5. 2018. http://www.citaliste.rs/citaliste_files/sabovljev_cikago_stil.pdf.

8. Williams Library. "Citing Your Sources: Chicago: Notes". Preuzeto 17. 5. 2018. http://library.williams. edu/citing/styles/chicago1.php.

\section{Chicago Style of Source Citation}

\begin{abstract}
Summary
Whether we see citation as retelling the words of others, as paraphrasing or summarizing someone's ideas or attitudes in order to confirm their own insight or argue with different opinions, or just directing readers to related works, it requires a clear and detailed bibliographic description of the source. This includes rules that provide information on the bibliographic unit. These rules vary from one to another citation style. The choice of style depends on the scientific discipline, the rules prescribed by journals, scientific publications, and the collections of works in which the articles are to be published, or the affinities of the authors themselves. This paper presents changes in the citation of different types of material and sources published in the seventeenth edition of the Chicago style of source citation, with practical examples. The Editorial Board of Čitalište: A Scientific Journal for Theory and Practice of Librarianship decided to apply Notes and Bibliography style (i. e. Humanities style), in accordance with the practice applied in journals dealing with library and information activity worldwide. This work presents the ways of citing different library and information material and sources which are most often used as referential literature in scientific or professional articles.

As can be seen from the new Guidelines, Chicago style of source citation has undergone significant changes compared to previous editions. Much more attention is given to electronic sources and content created in different social media. This is a consequence of the development of information and communication technologies and the influence of the media on all segments of life, including the scientific research.

Chicago style of source citation takes over the supremacy in the field of scientific research in humanities. In the Act on Editing Journals of the Ministry of Science and Technological Development of the Republic of Serbia, it is listed as one of the styles supported by the leading international databases for evaluation, as well as by the Serbian Citation Index. Therefore, knowing its rules is very important.
\end{abstract}

Keywords: citation, Chicago style of source citation, The Chicago Manual of Style - CMOS, bibliographic unit, footnote, bibliography, library and information material, sources 


\section{(),}

Чикаго стил библиографског цитирања by Драгана Сабовљев is licensed under a Creative Commons Attribution-NonCommercial-NoDerivatives 4.0 International License. 